\title{
A Portrait of the Rebel as an Artist: Deconstructing Post-coloniality in Francis Stuart's Black List, Section $\mathrm{H}$
}

\author{
Shahriyar Mansouri \\ Shahid Beheshti University, Tehran, Iran
}

Copyright (c) 2016 by Shahriyar Mansouri. This text may be archived and redistributed both in electronic form and in hard copy, provided that the author and journal are properly cited and no fee is charged for access.

\begin{abstract}
The historically 'interrogative' nature of the modern Irish novel introduces postindependence Ireland as a locus that is torn between social double standards and political extremes. Rebellious and critical voices channelled through the dialectical discourse of the novel and at once critiqued a State-sponsored voice of internal othering and narratives of decolonization. To sustain its relevance as a medium of criticism the modern Irish novel replaced the classical structure of the novel with narratives that tend to deconstruct the State's politics of formation. These narratives, this paper suggests, are inherently personal and structurally biographical, enabling the Irish to revisit the past and restructure their perception of critical concepts such as national identity, ideological intolerance, and individual formation. By examining Francis Stuart's Black List, Section H (1971), and John McGahern's The Dark (1965), firstly I will identify these resistant voices, which challenged and subverted the socio-political, and educational boundaries. Secondly, I will explore a dividing line that appeared between such critical voices, splitting them into critics who sought a liberated definition of Irishness rooted in the principles of the men of 1916, and rebels who demanded social recognition and political and commercial success. It is the latter group, I argue, that instead of enhancing the standards of life in Ireland became a threat to its very foundation.
\end{abstract}

Key Words. Modern Irish Novel, Francis Stuart, John McGahern, Post-coloniality, 1916 Rising.

Resumen. El carácter históricamente 'interrogativo' de la novela irlandesa moderna presenta a la Irlanda post- independiente como un locus que se debate entre la doble moral social y el extremismo político. Voces rebeldes y críticas se han vehiculado a través del discurso dialéctico de la novela y criticado la voz de la otredad interna patrocinada por el Estado así como narrativas de descolonización. Para mantener su relevancia como medio de crítica la novela irlandesa moderna sustituyó la estructura clásica de este género con narrativas que tienden a deconstruir el ideario político del Estado. El artículo sugiere que dichas narraciones son inherentemente personales y estructuralmente biográficas, permitiendo a los irlandeses revisitar el pasado y reestructurar su percepción de conceptos críticos como la identidad nacional, la intolerancia ideológica, y la formación individual. Mediante el análisis de Black List, Section H (1971) de Francis Stuart y The Dark (1965) de John McGahern, en primer lugar voy a identificar estas voces resistentes que desafiaron y subvirtieron los límites sociopolíticos y educativos. En segundo lugar, voy a explorar la línea divisoria que apareció entre tales voces críticas, escindiéndolas en aquellas que buscaban una definición liberada de la identidad irlandesa arraigada en los principios de los hombres de 1.916, y en voces rebeldes que reclamaban el reconocimiento social y el éxito político y comercial. Sostengo que este último grupo, en lugar de mejorar los estándares de vida en Irlanda hizo tambalear sus cimientos.

Palabras clave. Novela irlandesa moderna, Francis Stuart, John McGahern, Post-colonialismo, Levantamiento de 1916.

ISSN 1699-311X 
Among Subjective men (in all those, that is, who must spin a web out of their bowel) the victory is an intellectual daily recreation of all that exterior fate snatches away; while what I have called 'the mask' is an emotional antithesis to all that comes out of their internal nature.

William Butler Yeats, The Trembling of the Veil 1922: 74.

\section{Introduction}

For Fredric Jameson, the 1960s were the "transitional period, a period in which the new international order (neo-colonialism, the Green Revolution, $[\ldots])$ is at one and the same time set in place and is swept and shaken by its own internal contradictions and by external resistance" (Jameson 1998: 3). Ireland was not much of an outsider to the ubiquitous rise of this international order, as the 1960s marked the beginning of socio-cultural revolutions whereby the Irish re-discovered their rooted individualism. ${ }^{1}$ Moreover, it was the very same period, as Augustine Martin aptly identifies in "Inherited Dissent", that the Irish and the Irish society converged yet for the second time after the revival at the "crossroad" of literature (1965: 13). Having been disconcerted by residues of conservatism, the Irish were led by this fissure to welcome and instrumentalize the novel as a historically aware critical discourse, narrating the nation's plights of individual formation overshadowed by national independence.

As Declan Kiberd claims, in Ireland while the 1920s and the 1930s were about introspection, and the 1940s and the 1950s about socio-cultural introversion, the 1960s, and especially 1965 onwards, witnessed a revolution in the nation's perception of individual and national identity (1997: 47180). Rebellious voices channelled through the critical discourse of the novel, and critiqued a State-sponsored voice of internal othering and narratives of decolonization. ${ }^{2}$ According to Gerry

1. On re-discovering Irish identity see Kiberd (1997: 25-55). On rooted individualism as an independent appreciation of Irish identity see Daly, Industrial Development and Irish National Identity, 1922-1939, New York: Syracuse University Press, 1992.

2. On Irish nationalism as a voice of internal othering see Robert Kee, The Green Flag: A History of Irish Nationalism, Dublin: Penguin, New Edition, 2000, 650-5.
Smyth, "the Irish subject", split between such conservative extremes, "functioned as an effect of this or that narrative, placed here or there depending on where the commentator started, the direction he took, and his imagined destination" (1999: 212).

To maintain its currency as a medium of socio-cultural criticism, the modern Irish novel must first challenge and subvert yet another socio-political obstacle, namely, the oppressive society normalized by the State. As Kevin Kiely identifies, narratives that tend to replace the State's politics of formation with a personalized account of individual formation generally share a similar fate, namely, receiving "negative [and] disheartening" responses from not only various political parties, publishers, and numerous Censorship Acts but also readers as the very components of society (2008: 243). Socio-culturally nonconformist modern Irish authors such as Francis Stuart, Flann O'Brien, James Joyce and Samuel Beckett, to name but a few, in this respect, were further bracketed by society's dualistic preference either as "monarch[s] of Irish letters" or absurdist "outsider[s]" (Kiely 2008: 242). Through the critical discourse of the novel (of formation), for instance, these critics tap into socio-politically conscious memories that, as Linda Hutcheon claims, enable the nation to "transcontextualize" their historical memory, namely, revisiting the past and restructuring their perception of critical concepts such as national identity and formation, racial and ideological intolerance, and a marginalized understanding of individual formation (2000:102).

In this article, by examining Francis $\mathrm{H}$. Stuart's "self-reflexive tongue-in-cheek"Black List, Section H (1971) and John McGahern's The Dark (1965), firstly I will identify the modern voices that challenged the sociopolitical, and educational boundaries that were established by the State and legitimized by the Constitution (Cleary 2007: 175). Secondly, I will explore the dividing line that appeared 
between these non-conformist voices, splitting them into critics who sought a liberated definition of Irishness rooted in the revolutionary principles of the men of 1916, and those who distanced their principles of formation from, for instance, the State only to gain social recognition, and political and commercial success. It is the latter group, as I shall examine shortly that instead of enhancing the Kiberdian concept of life in Ireland as a national standard of internal unity and liberation became a threat to its very foundation, embodied by extremists and opportunists such as the separatist rebels in Stuart's Black List, Section H. $^{3}$

While Kiely categorizes "commentators and critics" of this rebellious voice prevalent in the works of Stuart, Joyce, and Beckett as "those who revile [it] and those who support" it, I argue that in the 1960s even such a dualistic preference was met with an inner division (2008: 325). On the one hand, these were revolutionaries who supported the State's normalized definition of non-colonial formation; and on the other, they were the very critics like Joyce and Stuart who followed their self-referential pattern of formation, eventually leading to the pluralist Ireland of the late 1970s and the 1980s. It is the latter group, I argue, who embody what I shall call the unconventional Dedalus -ism, becoming those who seek Irishness in an un-Irish critical definition, and pursue rootedness by indulging in what Edward Said regarded as the key to having a detached yet reliable perception of social formation by being "an outsider, living in self-imposed exile, and on the margins of society" (1993). Stuart, in this respect, emerges as a manifestation of such a detached, Edwardian voice that re-appeared in the 1960s and critiqued the nativist definition of Irishness. He emerged as a critical rebel, albeit completely controversial, who claimed that "national literature is [...] a meaningless term", as for him "literature can't be national. Literature is individual" (Stuart 1979: 408). Such a radical personalization of literature, according to Kiberd, tends to replace national

3. On the concept of Life in Ireland, see Declan Kiberd (1997:10-5). historiography with personal biographical history of life in Ireland and life of Ireland:

In such a self-charged context, nation-building can be achieved by the simple expedient of writing one's autobiography: and autobiography in Ireland becomes, in effect, the autobiography of Ireland. To read the autobiographies of Yeats, George Moore or Frank O'Connor is an experience [...] to constantly impressed and unnerved by the casual ease with which they substitute themselves as a shorthand for their country, writing an implicit and covert constitution for their republics in images of their very creation (Kiberd 1997: 119).

Stuart wrote Black List, Section H in 1966 after his return from Germany in 1958, a return that brought him at once controversy and recognition, becoming a "towering" literary figure, as Kiely notes, who provoked both criticism and admiration (Kiely 2008: 242). ${ }^{4}$ Black List, Section H, his most notable work, chronicling the protagonist's "journey of inner formation" from 1918 to the late 1940s (Molloy 1989: 43), initially was titled as "The Legend of H", which, in its Kiberdian sense, ${ }^{5}$ explored the Irish life and simultaneously the life of Ireland under the influence of a politically conservative State and an oppressive society. True to its neoconservative nature, the seemingly tolerant Irish society made the process of publication even more dreadful for critics such as Stuart, by marginalizing Black List, Section $H$ and disregarding it for its "subversive" methodology in engaging with Ireland's conservative sub-culture of provincialism, parochial stasis and containment (Kiely 2008: 243).

Not only was Stuart's Black List, Section H unique in its rebellion against the State's provincialism, distancing itself from the Joycean teleological dictum of non-serviam, but it emerged as a worthwhile replacement for the resistant literature produced by modern non-

4. The controversy had to do with his political propaganda that was broadcast from the Nazi Germany during the Second World War, which linked him to anti-semitism.

5. On the differences between 'the Irish life' and 'life in Ireland', and on modern Irish novels as personalized narratives of national formation see Kiberd (1997: 118-22). 
conformists such as Joyce. That is, Stuart's Black List, Section $H$ emerges as an exemplar of Theodor 's Negative Dialectics by seeking identity and independence in that which is socially unknown, unexperienced, nonidentarian. Black List, Section $H$, in this respect, can be read as a modern text critical of the conventional perception of Irish life, and introduces a deconstructionist reading of the State's fallacy of provincialism. For instance, during his first meeting with Iseult, his wife-tobe, threatened by Yeats's inspiring intellectualism, Stuart's protagonist Henry Ruark, known as $\mathrm{H}$ throughout the narrative, forms a personal negative dialectics not only to defend his perception of modern Irish Bildung but also to voice his concerns vis-à-vis bourgeois stereotypes and clichés:

A poet must be a countercurrent to the flow around him. That's what poetry is: the other way of feeling and looking at the world [...] if society honours the poet, he's tempted to say what those in authority expect from him. They wouldn't have honoured him otherwise, would they? But the poet will only come out with the sort of truth that it's his task to express when he lacks all honour and acclaim. Oh no, no honours, no prizes, or he's lost! (Stuart 1971: 17). ${ }^{6}$

Black List, Section H, I suggest, can also be read as a critical medium that served the dialectical outcry of youth in two separate ways. First, the retrospective nature of the modern Irish novel allowed the youth to critically revisit their historical memory and reconstruct the events of their blighted beginnings by questioning the very impulses that led to revolution, partition, and the rise of neo-colonialism. Second, the polyphonic structure of the novel would empower the youth to externalize and narrativize their efforts that ended in breaking away from the State's dichotomous treatment of Irish life, subverting the binary of submission or marginalia. Stuart's radical dialogism, in this respect, transforms into a dialectical discourse

6. Citations in this study refer to the first edition of Stuart's Black List, Section $H$ published by Southern Illinois University Press in 1971. which deconstructs an illusory perception of postcolonial reality in Ireland by describing a nation-wide state of paralysis, division and provincialism. Such a deconstructionist heritage can be seen in Stuart's later works such as A Hole in the Head (1977) whereby the voice discards Irish postcoloniality as a "dream-within-dream" and a "drug-induced hallucination" (13).

Black List, Section $H$ can too be read as a subversive narrative of deformation. The narrative depicts a crossroad where the protagonist's non-identarian quest for rootedness meets with an individually artistic denial of a Joycean aesthetico-spiritual pattern of formation. For Stuart, in this respect, the Joycean pattern of childhood, adolescence, student life and then resistance is at once incomplete and archaic for it seemingly has forsaken the undisputable status of art in one's pattern of personal and national formation. Black List, Section $H$ includes an unabashed reflection of the modern youths' nonconformist formation through the characterization of $\mathrm{H}$, Stuart's fictional surrogate for himself. $\mathrm{H}$ stands at the frontier of post-Joycean characterization whereby the authorial voice (of Stuart) could narrativize not only his cyclical psychosocial development, namely, from a young student and fervent poet to a soldier, gambler, literary figure, lover, drunkard, war veteran, and yet again a notable but silent, literary scholar but also his understanding of the significance of art in breaking away from what Anibal Quijano regards as the clichéd "coloniality of power" in postcolonial nations (2000: 540),

Although he was still far from coming to understand the necessity for what had happened to them, he did begin to see the silence that he had entered as the deep divide between the past and what was still to come. Whatever it was that was at the other end there was no way of telling. It might be a howl of final despair or the profound silence might be broken by certain words that he didn't yet know how to listen for (Stuart 1971: 425).

To advance his non-conformist becoming, $\mathrm{H}$ needs to satisfy his desire for detaching from society's clichéd thus identarian politics of conformity. $\mathrm{H}^{\prime}$ radical understanding of non- 
conformity. $\mathrm{H}^{\prime}$ radical understanding of nonidentarian formation confirms a Deleuzian dualistic perception of desire. For Gilles Deleuze and Felix Guattari, the individual's desires are the very impulses that "deterritorialize", namely, stop the individual from internalizing colonial norms by deconstructing such norms, be they colonial, post-colonial or neo-colonial (1986: 113-4). Desire, in other words, emerges as the very force that leads the individual from a normalized and hence a territorialised definition of individuality towards an individually productive, independent understanding of society. Such a drive internalized by critical voices such as Joyce's Stephen Dedalus and especially Stuart's $\mathrm{H}$ further marks them as individuals who desire the forbidden, namely, a self being detached from the social identarianism of postcolonial Irish identity.

$\mathrm{H}$, a blurred reflection of Stuart's own radical, inward self-formation, as Francis Molloy argues, emerges as "the artist in rebellion", and an unsparing critic of his society who is "in savage opposition to the mass values around him" (Molloy 1989: 38). Such a rebellious manifestation of the artist, Molloy claims, depicts "the conflict between the artist and the conventional values", and demands that which is labelled as forbidden by engaging in the dialectical discourse of his narrative (1989: 38). H defines his quest for the unknown by identifying with rebels and those who defy the State-imposed norms such as the IRA, who he introspectively once considered as the enclave of republican opposition group.

Non-conformity, rebellion and challenging the complacent State, according to H's PostJoycean perception of formation, is equal to nothing but maturation. He is shown "delighted in hearing of riots, no matter where, in civil disturbances, even in bank robberies", revealing a Foucauldian dissidence in $\mathrm{H}$ (Stuart 1971: 20). $\mathrm{H}$ emerges as a dissident artist in Deleuze's canvas of "minor literature" who finds pleasure in deconstructing the State's structure of territorialisation and discipline (1986: 20). The way Stuart's artist attacks the neoconservative State and its normalizing literature is twofold: first by appropriating the national language as its medium of nationwide criticism, confirming Deleuze's concept of minor literature whereby the dissident author pens their individual and national concerns in the form of a manifesto or literature. Second, by condoning a reversal of the coloniality of power, where "assassinations and anything that diminish[s] or throw[s] doubt on authority" is acceptable "as long as the result [is] like that of a stone dropped into a mill pond", the rebellious artist can subvert the State's Foucauldian 'power games' (Stuart 1971: 331). It is the latter, I argue, which allows Stuart's recalcitrant literature to transcend the Deleuzian framework of minor literature and become what I call a transnational literature. Such a rebellious form of literature not only deconstructs the State's politics of chastity and the neoconservative societal norms but also supplies the author with an ethical, albeit essentially personal, map of the terrain of national literature, demanding for the abolishment of State-sponsored, national literature.

Stuart's controversial novel locates the origin of such a blanket dissent among the Irish in the formation of the State's double standards after the nation unites for reform. To steer its messianic account, the novel focuses on an ontological portrayal of the divide by chronicling the 1916 Rising, the revolution, and the 1920s. In so doing, the narrative introduces Henry Ruark, a nomenclatural symbolism for the discontented younger generation, and depicts the development of a growing affinity between H's rebellion and the opposition group, namely, those who in H's eyes lay the foundation of liberated formations and individualism in Ireland. The shared values, namely, $H$ 's criticism and the opposition groups' ethos of dissent, not only target the State's authoritarian presence denouncing it as irrelevant and limiting, but they also function as what Deleuze (2002) regards in The Desert Islands as the "individualistic instinct", which questions the relevance of other normalizing institutions and principles such as religion, marriage and family, and society (19). It is H's Deleuzian individualistic instinct, for instance, which dismisses the nativist Irishness as a "lofty idealism" in which one's being and sense of belonging would equal "clinging to a concept of an Ireland in which the Church and the 
Gaelic League would be [the] dominant" irrevocable impulses (Stuart 1971: 80). For H and the like-minded critics, such a static provincial territorialization resonates with a traditional society-induced "mass enthusiasm" that has led the Irish towards failure and stasis for the past centuries, a colonial paralysis caused by socio-political "complacency", lack of sceptical dialectics, and critical discourse to help the nation critique their national status (Stuart 1971: 20).

Understanding personal formation under such a negative dialectical discourse and perception of Irish life, crystalized in H's rite of becoming, results in the emergence of a culture of "scepticism" which enables the Irish to question and deconstruct the "easy assumption" of the masses, namely those who have submitted to the State's architecture of formation, and who believe in the "absolute rightness and moral purity of the nationalist causes" (Stuart 1971: 20). As such subtle shades of individualist, non-conformist tendencies transform into an essential mode of thinking for critics such as $\mathrm{H}$, they interpret formation and individualism as a contradictory binary in their Irish formation, and thus interpolate radical concepts such as separatism and inevitably social disorder into the fundamentals of the concept of becoming. The protagonist in such narratives identifies with a sense of individualism that oscillates between the Deleuzian concept of differential presence and self-cancellation.

As Deleuze argues, differential presence should be read as neither an arrival nor an end to a process of critical becoming; rather, it should be considered as a state of creative formation which ends in the development of a socially conscious individual, whose criticism targets immature power games or mature colonialities (Leitch 1983: 133).To this end, H's oscillation confirms the Deleuzian notion of differential presence as his presence in his self-referential narrative of postcolonial Ireland appears as a volatile presence of an individual within a politicized context, whose dialectics constantly clashes with a State that exercises dominance and normalization. Protagonists such as Stuart's H, in this respect, emerge as personae non gratae who are torn between the contradictory triumvirate of traditionalism, nation- ism and the Irish Church on the one hand, and the dissolving radicalness of modernity and modern thought in the form of young Irish rebels on the other. Such a divide, for instance, is manifested in H's private conversations with his wife, Iseult, wherein $\mathrm{H}$ embodies such radical dialectical discourse while Iseult represents the nativist static conservatism:

$\mathrm{H}$ was not an apt pupil, especially for the sort of teaching that treated religion as a cut-and-dried subject, with hard-and-fast rules to be meekly memorized [...] she screwed up her eyes and told him that it was presumptuous to talk like that $[\ldots]$ her introduction of the mystics silenced him. All the same he wasn't satisfied (Stuart 1971: 28).

As $\mathrm{H}$ understands, by embracing isolation and detaching himself from the dominant culture of submission "his world [would] expand all the time, growing richer"; however, he is depicted to be conscious about the fact that by joining the rebels and becoming one himself he might risk his social significance as a rebellious intellectual altogether, for "there was this half-conscious fear that [his life] was also being impoverished" and deprived of proper social and intellectual integrity (Stuart 1971: 39). Critics like H, representing the modern Irish protagonists, embrace chaos, "riots, $[\ldots]$ and anything that diminishe[s] or throw[s] doubt" on representations of authority only to express their dissatisfaction and concern with the post State (Stuart 1971: 20). The concept that joins $\mathrm{H}$ and the socio-political rebels is the idea of constructing an ahistorical, anti-nativist dialectical structure in which "familiar habits and conventions [could be] swept away... and nothing was disallowed to the daring ...", as whatever "could be imagined could be made come true" (Stuart 1971: 85). It is H's radical reading of his socio-temporal situation which introduces him as a postJoycean protagonist who critiques the narrowness in appreciating the history of not just Irish life but life in Ireland by maintaining a different look at Ireland.

H's interpretation of formation, I suggest, is founded on transforming into a detached, individualistic consciousness that strives towards achieving certain self-set objectives, which then collectively contribute to his formation. As H reveals, however, rebels' 
principles are centred on one collective objective that would lead to neither formation nor deformation, but rather to an anarchic hegemony. . For H, rebels' ethos of formation will "coarsen the texture of sensibility and lower the imaginative level", just as nationalists' politics of stasis and conservatism would deprive the artist of achieving proper Bildung (Stuart 1971: 73). As H understands, reintegrating into "restricted, tight-knit communities where influences from without are the more easily rejected as unpatriotic, irreligious, or, a condemnation that gains popular approval in such situations, treasonable' is only 'welcomed by mediocre minds" (Stuart 1971: 73). For H's rebellious psyche, however, isolation and formation through war and ideological division are at once spiritually destructive yet beneficial to the artist's psychological formation, for as $\mathrm{H}$ claims, "war creat[es] doubt and confusion, and thus a climate in which the poet could breathe more easily" (Stuart 1971: 72-3).

Through what Yeats (1922) referred to as "intellectual daily recreation" (74), namely, rebellion and criticism, $\mathrm{H}$ as a modern Irish artist finds himself capable of deterritorialising the "traditional values and judgments", and then discovering, developing and advocating his own artistic pattern of formation (Stuart 1971: 74). However, such socio-cultural subdivisions, or in H's terms "small enclaves of [...] true revolutionaries" also pose a threat to H's intellectual and artistic utopia, heralding the fall of Irish society and deconstruction to various detached sub-societies and selfreferential sub-cultures as in catholic and protestant, urban and rural, revolutionary and counter-revolutionary, republican and unionist and so on (Stuart 1971: 74). That is to say, while doubting nativists' passivism was what $\mathrm{H}$ and rebels truly embraced, challenging Irishness or denouncing their rootedness was at once unacceptable to either sides of the conflict. As $\mathrm{H}$ reflects, most of the IRA rebels whom he "met at his mother-in-law's" house had mistaken apolitical, liberating nonconformism for unruly and chaos (Stuart 1971: 74). For $\mathrm{H}$, the egoist anarchism embedded in non serviam should be directed towards the nativist stasis and retrograde formation; while for rebels anarchic formation erroneously meant following "a one-track, political approach to something that $[\ldots]$ had other more complex aspect[s]" (Stuart 1971: 74-5). It was because of such an instrumentalized perception of revolution that $\mathrm{H}$ decides to distance his liberating non-conformism from IRA's blind political rebellion, especially when he "realize[s] how little politics could ever concern him with their large-scale, impersonal values"; and when "lack of idealism", while defying authority, has transvalued into becoming a distinct value (Stuart 1971: 75).

Rebels' fundamental principles, as $\mathrm{H}$ narrates, resonate with those which laid the foundation of the minor resistant literature, namely, extremism and non-objective revolution. According to David Lloyd's Deleuzian reading of minor formations, ${ }^{7}$ the notable features that minor literatures have lacked since their formation are "produc[ing] narratives of ethical identity, [which] is generally refused in minor writing..." and yet at "the same time ... is the very retention of a project aimed at securing [an] identity that ... creates a disjunction between the desires of the characters and the effect of the text" (1992: 22 ). While in both cases the resistance appears inherently anarchic and anti-political, it is H's Yeatsian appreciation of recreation, being wedded to his desires for the forbidden, that redefines objectively dull anarchic jolts and develops a critical discourse to understand and analyse society and societal norms. The result emerges as a critical, aesthetic matrix in which (inner) self-cultivation becomes the only objective that enables the author or artist to critique the territorialised society.

For critics such as Stuart and H, war, Irish nationalism and even Irish revivalism concur with Max Stirner's perception of religions, humanity and God. Stirner regards these concepts as "egoist" and arrogant causes that only prioritize and advocate their objectives and development; and so does $\mathrm{H}$ when he reflects on the significance of Irish wars and their relevance to his appreciation of formation (1995: 4). That is, Stuart's Irish modernism, a non-

7. On the onset and the origin of minor literature see Gilles Deleuze and Felix Guattari, Kafka Toward a Minor Literature (1986). 
identarian interpretation of modernism, transforms into the very cause that provides him with a leeway to distance himself from an instrumentalized pseudo-non-identarian Irishness that rebels and opposition groups utilized only to further their own cause:

He had seen enough of the civil war to grasp the fact that it hadn't much to do with him after all. Under either De Valéra or Griffith, art, religion, and politics would still be run by those who at best used them to give them power, prestige, and a good living, and at worst, for this to $\mathrm{H}$ was more dangerous, as a means toward sterile, high-toned conformism (Stuart 1971: 90).

The "lofty" and politically instrumentalized revolution for non-conformists such as $\mathrm{H}$, therefore, equates with "clinging to a concept of an Ireland in which the Church and the Gaelic League would be dominant", namely, a psychologically colonised society which demanded such radical responses from the masses in 1916, 1919 and 1921 (Stuart 1971: 80). For $H$ this appears as a society territorialised by the State's principles of normalization and dominance in which individualism and mental independence were either regarded as sacrilege and thus banned or blacklisted under the rubric of being "one of the Irregulars," when "found with" anything that could jeopardize the State's politics of formation, even "with contraceptives" (Stuart 1971: 81). During and after the wars of independence, the nation once again suffered from yet another ideological divide, which split the nation into those who supported the AngloIrish Treaty, i.e. Pro-Treatyites, and the Irregulars or Anti-Treatyites, who found the treaty supported by Michael Collins, Arthur Griffith, Eimar O'Duffy, as anomalous and abominable. As O'Duffy recounts in The Wasted Island (1920), the divide was more than a simple armed clash between the Irish and the Irish, leaving the nation with the duality of us and them.

As $\mathrm{H}$ experiences the State's postcolonial politics of division, and at once recognizes rebels' lack of idealism and critical ineptitude he embarks on a new and final path of formation, namely, "a private war which he hoped might cause a few cracks in the walls erected by generations of pious and patriotic Irishmen around the national consciousness"
(Stuart 1971: 82). Not only does he plan to question the extremes at either sides of the duality of Irish formation through his sceptic dialectical discourse at the heart of his narrative of formation, but he also recognizes "imaginative and undogmatic mood [...] as the prerequisite of true revolution" (Stuart 1971: 82). H's perception of formation relies on a variety of Joycean perception of aestheticospiritual education, namely, the sort which is confined by neither theoretical-political nor $\mathrm{H}$ 's personal and thus dogmatic boundaries of artistic formation. For as $\mathrm{H}$ understands, the former has promoted "generations of pious and patriotic Irishmen", while the latter involved H in the IRA's arms trade (Stuart 1971: 82).

The Rebel as a Mentor: Education, Nonconformity and Formation

Francis Stuart's stylistic as well as ideological rebellion has been more than a source of inspiration to known and unknown Irish moderns such as John McGahern. ${ }^{8}$ The Coloured Dome (1932), Stuart's third novel, for instance, not only functioned as a source of insight to McGahern's revelatory novels such as Amongst Women (1990) and The Dark (1965), by centring on a protagonist who intends to sacrifice his (family) life for the Cause, but as Yeats identified pioneered a contextual consciousness that would "make you understand the strange Ireland that is rising up here" (1954: 799-800).In this light, McGahern continues Stuart's critical pattern and builds the narrative of The Dark around a critique of the (in)significance of education in post-independence Ireland.

McGahern's The Dark chronicles the solitary journey of its young protagonist towards a socially normalized aesthetic ideal, namely, studying for scholarship and entering university, a journey which promises transformation and

8. On Stuart's literary influences on his contemporaries, especially John McGahern, see Kiely (2008: 85-90). Also see T. McGonigle, "The Story of his Life", in Los Angeles Times, February 26, 2006; and Brian Hughes, "Remembered Light: Constance in the Fiction of John McGahern", Revista Alicantina de Estudios Ingleses 5 (1992: 93-105). 
final recognition for its socially oppressed young protagonist. McGahern's young protagonist, unlike Stuart's non-conformist H, suffers from society-induced self-criticism and severe marginalization imposed by not just his conservative society but also his socially aggressive, promiscuous father. To escape from his own personal promiscuities, and social insignificance, the protagonist must prioritize between his choices of personal, subjective aesthetic ideals of art and education and socio-historical ideals of his conservative post-independence society.

McGahern's protagonist, however, has already subverted the State's obsessive dialectics of physical decency, or in Jonathan Bolton's terms, "politics of chastity" by territorializing his sexual pleasures and separating them from social norms by indulging in autoerotic pleasures (2010: 125).This self-indulgence in self-induced pleasures can be read as not only the first instance of defying the authoritarianism of the Church but also an unconscious, internalized echo of the Church's definition of formation: the protagonist shuns the outside world, and either joins the church and becomes a priest or shuts the world out and focuses on what shapes their internal world as in autoeroticism, education and maturation:

Bless me, father, for I have sinned.

Tell me your sins, my child.

I was guilty of impure action, father.

With a man, my child?

Yes, father.

Tell me what happened, my child.

Passionate kissing and embracing, father.

Were you touched [on the breasts], my child?

Yes, father.

In another sacred place as well?

Yes, father.

Did you actually have intercourse with this man, my child?

And what would you do? Stay quiet and begin, 'Don't you know, my child, that you are only permitted to do these things in Holy Matrimony [...]. Or would you sit quiet and excite your own seed in the box with your hand or pressing against the wood and let it flow in the darkness" (McGahern 1983: 55).

McGahern's narrative, in this respect, transforms into a self-contradictory narrative of pedagogical territorialization and sexual deformation whereby education, especially in its religious form, is either treated as an instrument of security or a means of subversion. The former can be achieved by shunning the unknown, outside world and imprisoning one's self within the boundaries of the State, while the latter is realized by contradicting the very ethos of formation.

Radicalness in the protagonist's understanding of education and pedagogical formation heightens when he regards priesthood as a socially preferred educational end for his rite of passage: "I thought you wanted to be a doctor?" "No. The course is too long. The scholarship only lasts four years [...] With the E.S.B., I'd be earning money straight away" (McGahern 1983: 183-84). Such an understanding, however, has less to do with the Joycean aesthetico-spiritual definition of education, and more with his Derridean understanding of formation and prayers as media that provide shelter and protection. In "Circumfession" Jacques Derrida (2005) defines the act of praying, and indulgence in the religiousness of prayers as the externalization of an innocent, and an internal need of being protected against societal and even familial complications, affixing the safety and relevance of the individual to the existence of a supreme force and abiding by its laws (22). ${ }^{9}$ Misguided by the patriarchal voice of the Church, McGahern's protagonist believes that by becoming a priest he may save her mother, or at least her soul. As the narrative unfolds in fact, such a radical ideological transmutation heightens when the protagonist's "mother ... go[es] away and [leaves him] to this"“"vapoury rush of thoughts", after which "nothing seemed to matter any more", as he only wanted to unlearn other ambitions of becoming, and just learn priesthood (McGahern 1983: 10).

However, there is another pole to the protagonist's binary of formation that dismantles his immediate ambition of becoming a priest, which is his obsession with masturbation, a sexual aberration that does not stop his individual formation; rather, it only redirects his psychological cathexis, leading it towards education. Instead of priesthood and

9. On the psychology of prayers see Jacques Derrida (2005: 19-28). 
saving his mother's soul, therefore, education as in the form of proper schooling sublimates his obsession with priesthood into securing social niche via literacy. That is to say, for McGahern's faceless protagonist education and priesthood both emerge as reachable instruments sanctioned by the State and society that may save him from himself, his family and a sexually unforgiving society. Through education, namely, by either becoming a priest or winning the scholarship, McGahern's protagonist effectively instrumentalizes a statesponsored definition of educational formation only to save himself from his morbid obsessions, his promiscuous father and priest uncle, and the haunting memory of his dead mother, creating a reliable psychological haven.

While for McGahern's protagonist education is nothing but instrumentalization of pedagogical norms and definitions, Staurt's $\mathrm{H}$ regards education as a means that will help the Irish remove the ideological and political divide that had split the nation. For $\mathrm{H}$, "imaginative and undogmatic mood" are by products of an unbiased, non-conservative education, and "the prerequisite[s] of true revolution" (Stuart 1971: 82). Namely, proper educational development stands as an un-Irish concept which would contribute to the deconstruction of the State's bipolar politics of formation. Unlike McGahern's protagonist's personalization of education, H's radical criticism appears as a radicalized variety of Yeats' intellectual daily recreation, where education is revisited by modern Irish protagonists as a means to enhance their critique of society by demythologizing the social bubble around statesmen, notable revivalists, and "generations of pious and patriotic Irishmen" (Stuart 1971: 82). In other words, while education was previously regarded as a means to improve one's social mobility and status, for the modern Irish protagonists such as $\mathrm{H}$ education is more a catalyst that would enable them to further deconstruct the colonial, postcolonial, and nativist triumvirate pattern of formation, and less a personal device to propitiate one's psychosocial traumata.

The way $\mathrm{H}$ re-invents self-formation initially resonates with a supra-individual impetus that connects the protagonist with a radical, albeit progressive, stream of social re-construction and political re-evaluation. This can be read in light of an Adornian description of formation: seeking formation in the unknown and the nondescriptive, "Should H say that he hadn't fought for anybody or anything, bit in pursuit of an obscure impulse of his own which had become somewhat clearer after he'd met with Lane? Could he explain Lane to Yeats?" (Stuart 1971: 142). H's self-referential nonidentarianism, in this respect, emerges as the very perception of becoming that has been charged by a Deleuzian bipolar, socially deconstructive drive, namely, the individual's desire. For Gilles Deleuze and Felix Guattari desire emerges as a non-conformist, radical, internal force that may lead to the production of an ideal society by deterritorialising the fascist norms on the one hand, and the internal implosion of Oedipal State through revolution on the other (2004: 163). The result is an antibourgeois binary of extremes, namely, modern self-formation and deconstruction of normalizing traditions. According to Stuart's H, such a radical combination results in a "kind of society, nearer [to] his largely subconscious dream", namely, a conceptual society which abides by no political territorialization while at the same time is governed by the individual's principles of unity and rootedness (Stuart 1971: 248).

$\mathrm{H}$ epitomizes the politically radicalized youth of the 1920s, torn between the complications of the internal wars and sociopolitical movements on the one hand, and the State's insular politics of localization on the other, or in his words "[A]ll his life [was] a mysterious attention, [which] controlled him and drew him toward things that surprised him and were often contradictory" (Stuart 1971: 251). These individuals represent a generation who disavowed the dominant socio-cultural logics of formation, and engaged in a selfreferential interpretation of the political atmosphere and "rebelled against what generally passed as the acceptable norm" (Stuart 1971: 257).They form a generation who in spite of their non-conformism, rebellion, and being on "the verge of something ... dangerously unknown" did not turn into an unbelievable psyche driven by an innate desire 
for chaos or destruction (Stuart 1971: 256-7). Rather, what they strived for was "a concept of reality deep enough to lose [themselves] in", namely, a liberating perception of the Free State in which individuals like $\mathrm{H}$ would not be marginalized by the State (Stuart 1971: 257).

Such a radical mentality also changed people's social interaction, as the young Irishmen transformed into idiosyncratic demagogues and became an antithetical definition for the concept of formation. To defy the canonical ethics and introduce contradiction and resistance as the core of modern coming-of-age, $\mathrm{H}$ and the like-minded critics needed to instrumentalize certain forms of knowledge. Sex, for instance, emerges as one of the most notable tools that provided non-conformists like $\mathrm{H}$ with a leverage to further deconstruct the State's neoconservative structure of formation. This realization of "knowledge" for $\mathrm{H}$ is "all-knowing, understanding, forgiving; it takes up no position, sets no store by form. It has compassion with the abyss - it is the abyss" (Stuart 1971: 363). In this light, while sensuality was frowned upon by society as an unexperienced taboo, for socially radical characters like $\mathrm{H}$ it functions as an agent, altered to target the core of State's politics of formation.

Such radical instrumentalizations, I suggest, can be read as Stuart's homage to Joyce's Wake, namely, creating a decentered textual society ruled by self-referentialism. In "Anarchy as the Wake", Roy Benjamin (2013) discusses the presence of a self-referential force within the very foundation of Joyce's magnum opus, Finnegans Wake. While Benjamin refers to Joyce's aesthetic formlessness as an attempt at deconstructing and decentralizing the State's politics of control, I find Stuart's anarchism materialized in his self-referential instrumentalizations of concepts as diverse as sexuality, religious disobedience, and personalization of art. In other words, it is the "vulnerability of the nucleus at the core of the cosmic structure" of a neo-colonial State, namely "the magic realm of sex that had always been barred against him", that appalled him (Stuart 1971: 375, 192).

As H reveals, for instance, "for those in a brothel, sex was no doubt something of a bore. Whereas the unexpected recollection of it in the middle of a day busy and preoccupied with the poultry [would] come as a delight" (Stuart 1971: 157). That is to say, for non-conformists such as $\mathrm{H}$, whose contradictory perception and instrumentalization of conventions define their radical psyche, sex, ideology, religion and social interaction were all but agents enabling them to "pursue $[\ldots]$ an obscure impulse of [their] own" (Stuart 1971: 141). Once again, Stuart's characterization of $\mathrm{H}$ resonates with the Foucauldian concept of modern man as both the justice and the crime: a dualistic abstract consciousness which at once finds himself guilty of abiding by his modern nonconformity, denies progress and deprives himself of it, and at the same time indulges in self-referential formation by demanding to be the centre of nation-wide critical discourse. H's non-conformist consciousness seeks to restructure society and national perception of formation, for "reality is nothing if not our most intense imaginative concepts of it' (Stuart 1971: 225).

\section{The Novel as the Rebellion: Individualism and Beyond}

The dawn of modernism and the negative dialectical psyche enabled Stuart's H as both the social subject and the antithesis to social subjectivism to think against the imposed social tide of Irish nationalism and nativism, or in Adorno's terms, to form by "think[ing] in contradiction" (1973: 145). By demythologizing the national definition of self-formation, Stuart's non-conformist protagonist transforms the narrative of social territorialization and passive subjectivity into a radical critique of identarian individuality, namely, a formation that is more about self-reflexivity and egoistic self-affirmation than self-cancellation. For H's self-referential psyche, for instance, history has been defined as not a retrograde reliance on the nation's glorious past but the one which is closer to his consciousness and can be felt by his, albeit limited, understanding of timeliness:

Reasoning can't distinguish true from false except on fairly extraneous levels. Do you never feel inside you, [...] a series of nerve cells, some sort of fine chain, linking you with reality? [...] each link a little more substantial as it comes 
closer to consciousness, transforming the vibrations into what can just, at the last link, enter the mind as thought (Stuart 1971: 167).

By approaching influential revolutionaries such as Yeats, $\mathrm{H}$ at once aims for social recognition, and defending his deterritorialized perception of Irishness. For $\mathrm{H}$, modern Irishness proper can be sought in a Yeatsian intellectual daily recreation of ideals and at once in the values of the men of 1916. While visiting Yeats and his family, $\mathrm{H}$ reiterates how his revolutionary ethos of formation would liberate the nation from the divide, a concept which already was testing Yeats's conservative nationalism. His answer to Yeats's question, "would the people you fought for have made better results?", therefore, is nothing but a stark portrayal of the nation colonized by the State's neocolonial principles of oppression and compliance (Stuart 1971: 141). According to Boyce (1995), Yeats and his fellow nativist revolutionaries understood such a candid depiction of the nation under the State's conservative politics of formation very late, namely, until they were well through the 1930s, and especially after the establishment of Constitution in 1937. "Should H say that he hadn't fought for anybody or anything, but in pursuit of an obscure impulse of his own [...] 'if you mean: would they also have imposed a censorship and forbidden divorce, I'm sure they would"' (Stuart 1971: 142). H's response, albeit egoistic, tends to rekindle certain revolutionary values in critics like Yeats, such as unity, rootedness, religious and civil liberty, and most notably commitment to equality and improving children's perception of individual formation. As Yeats (1916) recounts only retrospectively in his autobiographical writing, Reveries over Childhood and Youth, to "[begin] to feel that I had allies for my secret thought", that "it mattered to nobody whether the sun went round the earth or the earth round the sun" needed time beyond the patience of The Rising and Independence. Such an understanding of self-referential individualism, manifested in the discourse of critical voices such as $\mathrm{H}$, was not only belated but also 'secret[ive]' and personal.

While for many Yeats's efforts in joining forces with Hyde's Gaelic League to revive a nativist perception of Ireland was nothing short of national heroism, for critics like Stuart this form of heroism and the concomitant literature, which ignored minorities and oppressed dissidents for a conventional greater good, was just another national call for submission and conformity: "I don't know much about [Yeats]", remarks Lane - another nonconformist rebel, "but to me it sounds like a sellout [...] if he wrote the sort of poetry that told the truth he' $\mathrm{d}$ be more likely to have the other kind of noose slipped over it (Stuart 1971: 99). H "instinctively accepted what Lane said, yet at the same time he had to defend Yeats as a poet" and national hero (Stuart 1971: 99). This is the very dichotomous binary which controls H's perception of educational development, and especially how he as a poet and a rebellious artist should portray a proper liberating sense of formation. On the one hand, $\mathrm{H}$ finds young Lane's discontentment with the Yeatsian conservative heroism acceptable, and thus sympathizes with it later in his narrative when he discusses his own perception of literature and poetry as not just a means but a responsibility for him to visualize the plights of the nation. On the other, however, he feels the need to defend Yeats's messianic role as an artist, despite his seemingly conservative shortsightedness. "Literature to $\mathrm{H}$ was still somewhat of an abstraction"(Stuart 1971: 105), notes the narratorial voice, recounting his "unmitigated and unrepentant plea for radical individualism" and rebellious perception of what would lay the foundation of modern Irish literature (Stuart 1971: 105); as "for $\mathrm{H}$, literature was only to be experienced by those who dared pluck it direct from the tree of life" (Stuart 1971: 105).

H's non-identarian perception of literature, in contrast to Yeats's mesmerizing polemics of a national return to a Celtic utopia and unity, presents the poet as a "countercurrent" to the identarian, conservative "flow around him" (Stuart 1971: 17). H's definition of individuality, therefore, requires the individual to become someone who can not only "oppose censorship" but also challenge the conservative "safe parochialism" that originally legitimized censorship (Stuart 1971: 183). In other words, one should become a Foucauldian outcast whose creation would encourage the questioning of tradition as a manifestation of 
authority. For dissident critical voices like H, "better the infected sovereign psyche than one that shared in a general righteousness that didn't belong to it" (Stuart 1971: 369).

Stuart's modern novel not only remains faithful to what Smyth regards as a category with roots in national and individual subjectivity but also adds a more subtle function to its categorical existence by becoming a critical form which subverts the tradition of Irish novel by prevailing over the genre. This is a form which according to John W. Foster (2008: 939-40) dismantles the "belief that" the novel either "requires a preexistent social harmony" or should follow a predetermined pattern justified by its social integration. H's narrative of formation, contrary to the nativist ethos of socio-historical integrity and compliance, distances itself from such limiting principles and in so doing reshapes its telos to transfigure into a form that counterbalances the State's politics of stasis and compliance, while subverting the rebels' structureless hegemony. This, I argue, can be read as a prophetic role founded on H's nonconformist negative dialectical discourse:

If somebody somewhere writes a book which is so radical and original that would burst the present literary setup wide open, that writer will be treated with a polite contempt by the critical and academic authorities that will discourage further mention of him. He'll raise deeper, more subconscious hostility than sectarian ones and he'll be destroyed far more effectively by enlightened neglect than anything we would do to him here.

'You believe that the artist is bound to be rejected? You equate him with the prophet?'

'A poet may escape persecution because his vision is veiled from the literary arbiters, but the novelist who speaks more plainly is bound to scandalize them (Stuart 1971: 142).

While Stuart's Black List, Section H remains true to its culture of criticism and development, as H's narrative reaches its ending his critique of socio-cultural banalities and retrograde political development prevails over the genre of individual development and social integration, providing a sophisticated context for the emergence of a dialectical critique of conventional identity formation.

The dominance of criticism over genre in H's narrative can be understood in light of Julia Kristeva's interpretation of Jakobsonian definition of language, art and text. According to Kristeva, to deconstruct the identarian and conventional relationship between the sign and its social representation, as in Irish identity and its clichéd political representation, and the narrative and meta-language of conservatism and submission, the subject needs to develop a non-identarian form of the text. This radical perception of the novel imagined by $\mathrm{H}$, "cannot remain unaware" of the State's politics of submission and formation, as it "must move through them [...] seep into them, its violent rhythm unleashing them by alternating rejection and imposition" (Kristeva 1991: 160). This oscillation between rejection and imposition is manifested in H's understanding of literature, which is not national but personal, and unlike the literature produced by Hyde and Yeats has been "most conscious of exterior reality penetrating the fragile, deeply imagined one of the embryo fiction" (Stuart 1971: 398). Such a text, according to H's perception of individual formation, which foregrounds concepts such as "pain, guilt, and disaster as offering correctness of escape from selfimprisonment" (Stuart 1971: 392), resonates with Georg Lukács's definition of modern man and his inward literature .The text, according to Lukács (2006), emerges as an inclusive consciousness and creates a sub-reality to which norms and policies the modern individual can relate. This radical form of text not only has provided $\mathrm{H}$ a sense of belonging, rootedness and identity by offering him "a chance of becoming the only sort of writer it [was] in his power to be" but also has enabled other like-minded concerned voices to go beyond the boundaries of formation sanctioned by the State, and experience the Adornian unknown or in H's terms that which lies "outside the norms of experience", and reject the voice of the State, and develop and impose their self-referential voice and resistant text (Stuart 1971: 398).

As the narrative progresses, the selfreferential voice in H's narrative illustrates the dominance of criticism over genre by deconstructing Stuart's modern Bildungsroman and interpolating personal criticism in the text by touching on Ireland's dichotomous social norms, 
the State's neoconservative tendencies and nativists' retrograde mindset vis-à-vis a national perception of Irish identity. Therefore, the narrative, structured on a non-conformist omniscient voice, emerges as a heavily personalized account of the State's social shortcomings, and critiques a national conservative paralysis that should be dismantled. H's Kristevan perception of text does not recognize concepts such as nativist identarianism, the State's politics of forgetfulness, ${ }^{10}$ and a submissive sense of Irishness; for in H's negative dialectical discourse, "the praising of the trivial and mediocre that goes on all the time is even

10. On The State's politics of forgetfulness see James Smith, "Remembering Ireland's Architecture of Containment: 'Telling' Stories in The Butcher Boy and States of Fear" in Éire-Ireland: An Interdisciplinary Journal of Irish Studies 36, 3\&4 (2001): 111-30. more damaging to the formation of true values than the neglect of books of some originality" (Stuart 1971: 334).

\section{Conclusion}

Be it through its parodic, ironic unmasking of nationally cherished phenomena or its selfcentred renouncement of that which had become a pivot of national identity, Stuart's non-identarian novel transforms into a radically dialectical discourse which replaced conventional values, political intolerance, romanticized nationalist identity, and an identarian definition of individual Irish identity with self-scrutiny, and non-identarian selfcriticism. These are the concepts that allowed the modern Irish protagonist to think in contradiction, and appropriate a Deleuzian notion of desire as the internal impetus of formation, interpolating deterritorialization and critical re-formation as the emerging themes in the modern Irish novel.

\section{Works Cited}

Adorno, Theodor W. 1973. Negative Dialectics. Trans. E. B. Ashton. London: Routledge \& Kegan Paul. Benjamin, Roy. 2013. “Anarchy at the Wake.” Irish Studies Review 21.2, 203-16.

Boyce, George. 1995. Nationalism in Ireland. London: Routledge.

Brennan, Timothy. 1995. "The National Longing for Form”, The Post-Colonial Studies Reader, ed. Bill Ashcroft et alia. London: Routledge. 170-5.

Cleary, Joe. 2007. Outrageous Fortune: Capital and Culture in Modern Ireland. Dublin: Field Day Publications. Corcoran, Mary P. and Perry Share. 2008. Belongings: Shaping Identity in Modern Ireland. Dublin: Institute of Public Administration.

Deleuze, Gilles. 2002. The Desert Islands: and Other Texts 1953 - 1974. Trans. Mike Taormina. Paris: Semiotext(e).

Deleuze, Gilles and Felix Guattari. 1986. Kafka Toward a Minor Literature. Minneapolis: University of Minnesota Press. . 2004. Anti-Oedipus: Capitalism and Schizophrenia. Minneapolis: University of Minnesota Press.

Derrida, Jacques. 2005. “Composing 'Circumfession', Augustine and Postmodernism: Confessions and Circumfession, eds., John D. Caputo and Michael J. Scanton, Indiana University Press. 19-27.

Foster, John Wilson. 2008. Irish Novels 1890-1940: New Bearings in Culture and Fiction. Oxford: Oxford University Press.

Hutcheon, Linda. 2000. A Theory of Parody: The Teachings of Twentieth-Century Art Forms. University of Illinois Press

Hyde, Douglas. 2000 (1894). “The Necessity for De-Anglicizing Ireland”. Irish Writing in the Twentieth Century. Dublin, Cork University Press. 2-13.

Jameson, Fredric. 1998. The Cultural Turn: Selected Writings on the Postmodern, 1983-1998. London: Verso. Joyce, James. 2008 (1914). Dubliners. Project Gutenberg eBook. 
1989 (1909). “Oscar Wilde: Poet of 'Salome”, The Critical Writings of James Joyce. Ellsworth

Mason and Richard Ellmann, eds. Ithaca: Cornell University Press. 201-5.

1992 (1907). "Ireland, Island of Saints and Sages", The Field Day Anthology of Irish Writing 3. Ed.

Seamus Deane. Derry: Field Day Publications. 7-10

1996 (1916). A Portrait of the Artist as a Young Man. London: Penguin Classics.

. Finnegans Wake. 1999 (1939). London: Penguin - 20 Century Classic.

Kiberd, Declan. 1997. Inventing Ireland: The literature of the Modern Nation. Cambridge: Harvard University Press.

Kiely, Kevin. 2008. Francis Stuart: Artist and Outcast. Dublin: Liffey Press.

Kristeva, Julia. 1991. "Julia Kristeva Interviewed by Vassiliki Kolocotroni.” Textual Practice 5.2. 157-70.

Leitch, Vincent B. 1983. Deconstructive Criticism: An Advanced Introduction. Columbia University Press.

Letter of W. B. Yeats. 1954. Allen Wade, ed. London: Rupert Hart-Davis.

Lloyd, David. 1992. Nationalism and Minor Literature: James Clarence Mangan and the Emergence of Irish Cultural Nationalism. California: University of California Press.

Lukács, Georg. 2006 (1956). “The Ideology of Modernism”. The Critical Tradition: Classic Texts and Contemporary Trends. Ed. David H. Ritcher. Boston: Bedford Books. 1224-37.

Martin, Augustine. 1965. "Inherited Dissent: The Dilemma of the Irish Writer". Studies: An Irish Quarterly Review 40. 1-20.

McCabe, Patrick. 1993.The Butcher Boy. London: Picador.

McGahern, John. 2005.Memoir. London: Faber and Faber. 1983. The Dark. London: Penguin.

Molloy, Francis C. 1989. “A Life Reshaped: Francis Stuart's "Black List, Section H”.The Canadian Journal of Irish Studies 14.2. 37-47.

O’Duffy, Eimar. 1920. The Wasted Island. New York: Dodd, Mead and Company.

Quijano, Anibal and Michael Ennis. 2000. "Coloniality of Power, Eurocentrism, and Latin America". Nepantla: Views from South, Vol. 1, Issue 3.

Said, Edward. 1993. "Representations of the Intellectual”, The Reith Lectures. BBC Radio 4. <http://goo.gl/JpPbm.> accessed 10 March 2010

Smyth, Gerry. 1997. The Novel and The Nation: Studies in the New Irish Novel. London: Pluto Press. 220.

1999. "Irish Studies, Postcolonial Theory and the 'New' Essentialism", Irish Studies Review 7.2. 211-

Stirner, Max. 1995 (1907). The Ego and Its Own. Cambridge University Press.

Stuart, Francis. 1977. A Hole in the Head. Dublin: M. Brian \& O’Keefe. . 1982. “A Minority Report”, Irish University Review 12.1 Spring. 17-22 1971. Black List, Section H. Carbondale: Southern Illinois University Press. 1933. The Coloured Dome. London: Macmillan.

Yeats, William. 2006 (1916). Reveries Over Childhood and Youth. London: Macmillan. 2011 (1922). The Trembling of the Veil. London: Macmillan.

Received 1 December 2015 Last 27 December version 2015

Shahriyar Mansouri specializes in twentieth-century Irish novel, with additional interests in history and theory of the novel, historical fiction, biopolitics, and (post-) nationalist identity. Shahriyar is Assistant Professor of English at Shahid Beheshti University, Tehran, and IASIL regional Bibliography Representative for Iran. 